\title{
Is the Phenomenon of Mefenoxam-Acquired Resistance in Phytophthora infestans Universal?
}

\author{
Juliana González-Tobón, ${ }^{1}$ Richard Childers, ${ }^{2}$ Carolina Olave, ${ }^{1}$ Melissa Regnier, ${ }^{1}$ Alejandra Rodríguez-Jaramillo, ${ }^{1}$ William Fry, ${ }^{3}$ \\ Silvia Restrepo, ${ }^{1}$ and Giovanna Danies ${ }^{4, \dagger}$ \\ ${ }^{1}$ Department of Biological Sciences, Universidad de los Andes, Bogotá, Colombia \\ ${ }^{2}$ Department of Organismic and Evolutionary Biology, Harvard University, Cambridge, MA, U.S.A. \\ ${ }^{3}$ School of Integrative Plant Science, Plant Pathology and Plant-Microbe Biology Section, Cornell University, Ithaca, NY, U.S.A. \\ ${ }^{4}$ Department of Design, Universidad de los Andes, Bogotá, Colombia
}

\begin{abstract}
Phytophthora infestans is the causal agent of late blight disease of potatoes and tomatoes. This disease causes devastating economic losses each year, and control is mainly achieved by the use of fungicides. Unfortunately, populations of $P$. infestans resistant to fungicides have been documented. Furthermore, studies have reported that sensitive isolates to the phenylamide fungicide, mefenoxam, become less sensitive in vitro after a single passage through sublethal concentrations of fungicide-amended medium. The first objective of this study was to investigate if isolates of $P$. infestans are capable of acquiring resistance to two additional systemic fungicides, fluopicolide (benzamide) and cymoxanil (cyanoacetamide-oxime). In con-

of other Phytophthora species and of Phytopythium sp., another oomycete plant pathogen. All Phytophthora spp. assessed (P. infestans, P. betacei, and $P$. pseudocryptogea) as well as Phytopythium sp. acquired resistance to mefenoxam after previous exposure through medium containing $1 \mu \mathrm{g} \mathrm{ml}^{-1}$ of mefenoxam. Interestingly, isolate 66 of Phytopythium sp. and the isolate of $P$. pseudocryptogea tested do not seem to be acquiring resistance to mefenoxam after exposure to medium containing $5 \mu \mathrm{g} \mathrm{ml}^{-1}$ of this fungicide. The tested isolates of $P$. palmivora and $P$. cinnamomi were extremely sensitive to mefenoxam, and thus it was not possible to perform a second transfer to access acquisition of resistance to this fungicide.
\end{abstract} trast to the situation with mefenoxam, exposure of isolates to sublethal concentrations of fluopicolide and cymoxanil did not induce reduced sensitivity to these two fungicides. The second objective was to assess if reduced sensitivity to mefenoxam could occur in naturally sensitive isolates
Keywords: Phytophthora infestans, Phytophthora betacei, mefenoxam, cymoxanil, fluopicolide, mefenoxam-acquired resistance, Phytopythium sp., P. pseudocryptogea
Phytophthora infestans, the causal agent of late blight disease, is a filamentous plant-pathogenic oomycete responsible for the Great Irish Famine of the mid-eighteenth century. Since then, it has generated a broad interest due to the devastating losses it causes on potato and tomato crops worldwide, and it has been considered a model organism among the oomycetes (Kamoun et al. 2015). Control of late blight is mainly achieved by the use of fungicides. However, recent late blight epidemics have been associated with the emergence of new aggressive pathogen clonal lineages, which appear to differ in their sensitivity to some of the commonly used fungicides ( $\mathrm{Hu}$ et al. 2012; Saville et al. 2015).

In addition to the naturally occurring resistance against fungicides, in vitro induction of resistance has also been reported (Bruin and Edgington 1981; Childers et al. 2015; Staub et al. 1979). Tolerance to mefenoxam, a highly effective systemic fungicide to control late blight, has been observed after exposing previously sensitive isolates of $P$. infestans to sublethal (e.g., $5 \mu \mathrm{g} \mathrm{ml}^{-1}$ ) concentrations of the fungicide. This phenomenon, termed 'mefenoxam-acquired resistance', occurred on different genotypes of $P$. infestans after a single passage on mefenoxam-containing medium (Childers et al. 2015). The acquisition of resistance appears to have a fitness cost, given that isolates that had acquired resistance grew less on mefenoxam-free medium than the originally sensitive individual (Childers et al. 2015). Interestingly, it has also been reported that sublethal concentrations of this

${ }^{\dagger}$ Corresponding author: G. Danies; g-danies@uniandes.edu.co

Funding: The American Phytopathological Society partially supported this work through the 2017 Frank L. Howard Undergraduate Fellowship.

The author(s) declare no conflict of interest.

Accepted for publication 12 July 2019.

(C) 2020 The American Phytopathological Society same fungicide can induce in vitro oospore formation and change in mating type (Groves and Ristaino, 2000). Furthermore, after a few passages on mefenoxam-free medium, the amount of resistance appeared to decline (Childers et al. 2015). As suggested in Childers et al. (2015), a genetic mechanism, such as a mutation, seems unlikely due to the speed of adaptation, its apparent reversibility, and the fact that the phenomenon occurred in distinct genotypes of $P$. infestans. Therefore, a physiological or epigenetic mechanism regulating this phenomenon seems likely.

This study aimed to investigate the generality of this acquired resistance phenomenon. We did this first by assessing whether this phenomenon of acquired resistance in $P$. infestans might extend to fungicides other than mefenoxam. Mefenoxam is a phenylamide fungicide; we tested whether isolates of $P$. infestans were able to acquire resistance to two other systemic fungicides, fluopicolide (a benzamide fungicide) and cymoxanil (a cyanoacetamide-oxime fungicide), with modes of action different from that of mefenoxam (FRAC 2017). We next investigated whether the mefenoxam-acquired resistance phenomenon also occurs in other species of Phytophthora, as are Phytophthora betacei, Phytophthora palmivora, Phytophthora cinnamomi, and Phytophthora pseudocryptogea, as well as another oomycete, Phytopythium sp.

\section{Materials and Methods}

Isolates and growth conditions. A total of 13 isolates were used in this study, three of $P$. infestans, three of $P$. betacei, three of $P$. palmivora, one of $P$. cinnamomi, one of $P$. pseudocryptogea, and two of a different oomycete plant pathogen, Phytopythium sp. Mefenoxam sensitivity was assessed for all 13 isolates, whereas sensitivity to cymoxanil and fluopicolide was only assessed for isolates of $P$. infestans. Two of the three isolates of $P$. infestans (US150046 and IMK-1) were sensitive to all three fungicides. Isolate $\mathrm{RC} 1 \# 10$ was resistant to both mefenoxam and fluopicolide, but sensitive to cymoxanil. In the case of cymoxanil, no fully resistant isolate was available. Additionally, all other species tested in this study were originally sensitive to mefenoxam. Isolates US150046 (US-23) and IMK-1 (US-22) were 
used in this study as positive controls for the mefenoxam-acquired resistance phenomenon (Childers et al. 2015). All isolates were kept and routinely transferred onto pea agar ( $120 \mathrm{~g}$ of frozen peas, $15 \mathrm{~g}$ of agar, $20 \mathrm{~g}$ of sugar, and $2 \mathrm{~g}$ of $\mathrm{CaCO}_{3}$ for 1 liter of medium) (JaimeGarcía et al. 2000) and incubated at $20 \pm 1{ }^{\circ} \mathrm{C}$.

Initial fungicide sensitivity assays. For all $P$. infestans isolates, initial sensitivity to mefenoxam (RidomilGold SL, $45.3 \%$ a.i.; Syngenta), fluopicolide (Presidio, $39.5 \%$ a.i.; Valent), and cymoxanil (Curzate, $60 \%$ a.i.; DuPont) was assessed by measuring mycelial radial growth on fungicide-amended media relative to mycelial radial growth on the control plate (fungicide-free medium). For all other isolates, only sensitivity to mefenoxam was assessed.

Isolates were grown on pea agar amended with each fungicide to final concentrations of the active ingredients of: $0,1,5,10$, and $100 \mu \mathrm{g} \mathrm{ml}^{-1}$ of mefenoxam (Childers et al. 2015; Saville et al. 2015), 0, 0.1, 0.5, 1, and $10 \mu \mathrm{g} \mathrm{ml}^{-1}$ of fluopicolide (Keinath and Kousik 2011; Saville et al. 2015), and 0, 1, 10, 50, and $100 \mu \mathrm{g}$ $\mathrm{ml}^{-1}$ of cymoxanil (Saville et al. 2015). All petri plates were incubated at $20 \pm 1^{\circ} \mathrm{C}$. Three technical replicates of each isolate and fungicide concentration were done and the whole experiment was repeated three times (three biological replicates). Each biological replicate was done with freshly prepared medium.

Due to differences in growth rate among isolates, a standard colony diameter on the control plates was used to determine the period of incubation of each isolate rather than a standard incubation time (Childers et al. 2015). Colony diameter of each technical replicate was measured when mycelial growth on its control plate $(0 \mu \mathrm{g}$ $\mathrm{ml}^{-1}$ ) covered 80 to $90 \%$ of the petri plate. Mycelial growth at each concentration tested was recorded and presented as a percentage of the growth on the control plate. Measurements of radial growth were estimated by using a transparent acetate sheet of the same size as the

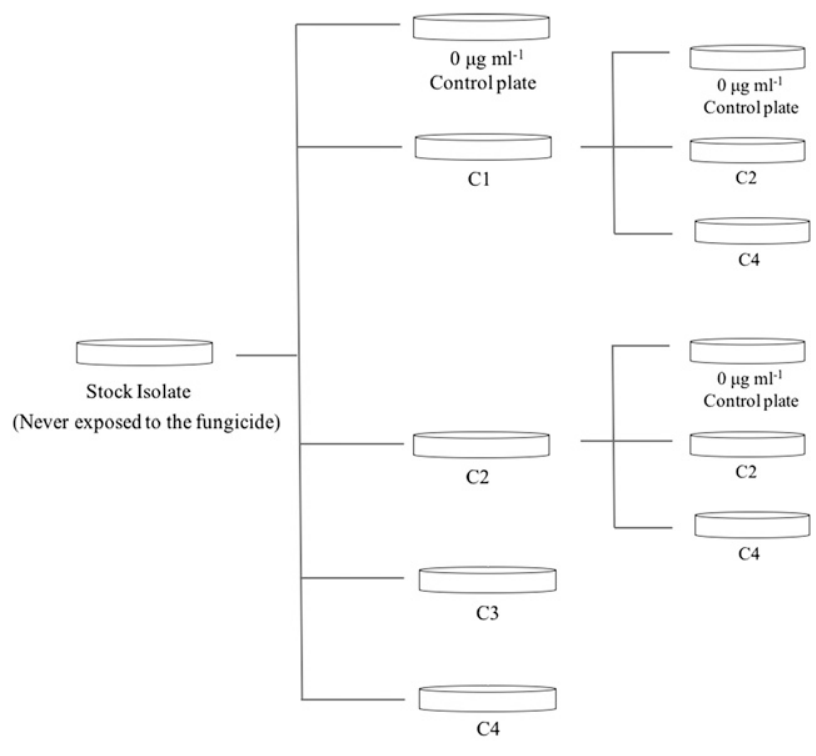

Initial sensitivity assay Acquired resistance assay

Fig. 1. General methodological process adapted from Childers et al. (2015). Initial sensitivity to three systemic fungicides (mefenoxam, fluopicolide, and cymoxanil) was assessed for three isolates of Phytophthora infestans (US1500046, IMK-1, and RC1\#10), three isolates of Phytophthora betacei (P1512-73, SBC3\#10, and N903562), three isolates of Phytophthora palmivora $(9,10$, and 88), one isolate of Phytophthora cinnamomi, one isolate of Phytophthora pseudocryptogea, and two isolates of Phytopythium sp. (112 and 66) that had never been exposed to either of the fungicides evaluated (mefenoxam, fluopicolide, and cymoxanil). Mycelial plugs from actively growing cultures of each of the isolates were independently transferred to a control plate $\left(0 \mu \mathrm{g} \mathrm{ml}^{-1}\right)$ and to media amended with four fungicide concentrations $\left(C 1, C 2, C 3\right.$, and $C 4$ which were $1,5,10$, and $100 \mu \mathrm{g} \mathrm{m}^{-1}$ for mefenoxam, $0.1,0.5,1$, and $10 \mu \mathrm{gl}^{-1}$ for fluopicolide, and 1, 10, 50, and $100 \mu \mathrm{g} \mathrm{ml}^{-1}$ for cymoxanil). For the acquired resistance assays, plugs from isolates growing at the two lowest fungicide concentrations, $\mathrm{C} 1$ and $\mathrm{C} 2$, were once again transferred to a control plate $\left(0 \mu \mathrm{g} \mathrm{ml}^{-1}\right)$ and to fungicide concentrations $\mathrm{C} 2$ and $\mathrm{C} 4$. petri plate with concentric circles drawn every $0.5 \mathrm{~cm}$. When placing the petri plate on top of this sheet, two perpendicular measurements starting from the widest diameter were estimated, and the average radial growth was obtained as done by Childers et al. (2015) and Saville et al. (2015).

To determine the percent inhibition (PI) for each isolate-fungicide concentration, the following formula was used:

$$
P I=\frac{(a-b)}{a} \times 100
$$

where $a$ is the colony radial growth of the control plate and $b$ is the colony radial growth of the fungicide-amended plate, as done in Rekanović et al. (2011)

The PI values were subjected to a regression analysis against the logarithmic values of the fungicide concentrations (Rekanović et al. 2011) using GraphPad Prism version 7.00 (GraphPad Software, La Jolla, CA, U.S.A., www.graphpad.com). A nonlinear regression model for data on inhibitory growth curves was used to calculate the effective concentration at which $50 \%$ of mycelial growth was suppressed $\left(\mathrm{EC}_{50}\right)$. For this calculation, a standard slope of 1.0 was defined, outliers were identified and removed, and normalized models were implemented in the cases where the PI values ranged from 0 to 100 ( $\mathrm{Li}$ et al. 2015). In the case of isolates for which mycelial growth was enhanced by the presence of the fungicide, the $\mathrm{EC}_{50}$ value could not be estimated and thus is presented as greater than the highest concentration tested.

Acquisition of resistance assays. The occurrence of 'acquired resistance' was assessed by comparing growth on fungicide-amended media between isolates without previous fungicide exposure and those same isolates after exposure to each of the fungicides tested.

Isolates that had never been exposed to the fungicides were initially transferred to medium containing 0,1 , and $5 \mu \mathrm{g} \mathrm{ml}^{-1}$ of mefenoxam, $0,0.1$, and $0.5 \mu \mathrm{g} \mathrm{ml}^{-1}$ of fluopicolide, and 0,1 , and $10 \mu \mathrm{g}$ $\mathrm{ml}^{-1}$ of cymoxanil. Subsequently, subcultures from colonies growing at the two mefenoxam-amended plates were transferred to medium containing 0,5 , and $100 \mu \mathrm{g} \mathrm{ml}^{-1}$ of mefenoxam; subcultures on fluopicolide were transferred to medium containing $0,0.5$, and $10 \mu \mathrm{g} \mathrm{ml}^{-1}$ of fluopicolide; and subcultures on cymoxanil were transferred to 0,10 , and $100 \mu \mathrm{g} \mathrm{ml}^{-1}$ of cymoxanil (Fig. 1). All petri plates were incubated at $20 \pm 1^{\circ} \mathrm{C}$ until mycelia on the new control plates $\left(0 \mu \mathrm{g} \mathrm{ml}^{-1}\right)$ reached 80 to $90 \%$ of the petri plate. The experiment was conducted three times (three biological replicates). Each biological replicate included three technical replicates. Mycelial growth was presented as a percentage of the average growth on the control plate.

To analyze if there was a significant effect of previous fungicide exposure on mycelial radial growth, a mixed model was constructed using restricted maximum likelihood (REML) in the $\mathrm{R}$ platform (Package lme4 and lmerTest, R Core Team 2012). To run the test, biological replicates were considered random terms and previous fungicide exposure was considered a fixed effect. This test evaluated if there were significant differences in the percent growth relative to the control $\left(0 \mu \mathrm{g} \mathrm{ml}^{-1}\right)$ of a single isolate growing at different subsequent concentrations after being exposed to different previous concentrations of the fungicide.

With the aim of investigating a possible cost in mycelial growth associated with the development of the acquisition of resistance, we recorded the time it took for the mycelia of isolates that varied in their previous mefenoxam exposure to reach 80 to $90 \%$ of the diameter of the control plates $\left(0 \mu \mathrm{g} \mathrm{ml}^{-1}\right)$. We performed regression analyses on these data using JMP 13.0.0 to see if this growth rate varied significantly (slope significantly different from 0 ) according to the isolate's previous exposure to the fungicide.

To test if the isolates that had acquired resistance to mefenoxam were able to grow at a concentration of $1,000 \mu \mathrm{g} \mathrm{ml}^{-1}$ of mefenoxam, which is the highest concentration tested on the mefenoxam sensitivity assays (Saville et al. 2015), subcultures from isolates US150046 and RC1\#10 that had been exposed to sublethal concentrations of the fungicide and that were growing at $100 \mu \mathrm{g} \mathrm{ml}^{-1}$ were transferred 
to pea agar amended with $1,000 \mu \mathrm{g} \mathrm{ml}^{-1}$ of mefenoxam as well as to a control plate $\left(0 \mu \mathrm{g} \mathrm{ml}^{-1}\right)$. As for the other assays, all petri plates were incubated at $20 \pm 1^{\circ} \mathrm{C}$ until mycelia on the new control plates $\left(0 \mu \mathrm{g} \mathrm{ml}^{-1}\right)$ reached 80 to $90 \%$ of the petri plate. The experiment was conducted three times (three biological replicates). Each biological replicate included three technical replicates.

\section{Results}

Initial sensitivity assays. Isolates US150046 and IMK-1 were sensitive to mefenoxam, while isolate RC1\#10 was resistant to the concentrations of mefenoxam that were evaluated (Table 1 and Fig. 2A). All other tested isolates, regardless of the species, were highly sensitive to mefenoxam (Table 1 and Fig. 2B to E). Similarly, isolates US150046 and IMK-1 of P. infestans were sensitive to fluopicolide, while isolate $\mathrm{RC} 1 \# 10$ was resistant to the concentrations that were evaluated (Table 1 and Fig. 2F). In the case of cymoxanil, the three $P$. infestans isolates evaluated were sensitive (Table 1 and Fig. 2G).

Acquired resistance assays. Mefenoxam-acquired resistance assays. The mefenoxam-acquired resistance assays successfully replicated the previously reported phenomenon in $P$. infestans isolates. In the initially resistant isolate, RC1\#10, no significant differences were detected in terms of mycelial growth between the isolate that had never been exposed to mefenoxam and that same isolate after exposure through mefenoxam-amended medium $(P>0.1$ when growing at $5 \mu \mathrm{g} \mathrm{ml}^{-1}$ and $P>0.5$ when growing at $100 \mu \mathrm{g} \mathrm{ml}^{-1}$ ) (Fig. 3A). However, the initially sensitive isolates, US150046 and IMK-1, grew more than they did initially in the presence of mefenoxam after a single exposure to low concentrations of mefenoxam-amended media (1 and $5 \mu \mathrm{g} \mathrm{ml}^{-1}$ ) (Fig. 3A). For both of these isolates, percent growth relative to the control $\left(0 \mu \mathrm{g} \mathrm{ml}^{-1}\right)$ increased significantly when growing at a subsequent concentration of 5 and $100 \mu \mathrm{g} \mathrm{ml}^{-1}$ of mefenoxam depending on the mefenoxam concentration to which these isolates had been previously exposed (for US150046, $P<0.01$ when growing at $5 \mu \mathrm{g} \mathrm{ml}^{-1}$ and $P<0.001$ when growing at $100 \mu \mathrm{g}$ $\mathrm{ml}^{-1}$; for IMK-1, $P<0.01$ and $P<0.001$ when growing at 5 and $100 \mu \mathrm{g} \mathrm{ml}^{-1}$, respectively). Isolate US150046 was not able to grow at medium amended with $1,000 \mu \mathrm{g} \mathrm{ml}^{-1}$ of mefenoxam even after acquiring resistance to this fungicide. However, the originally resistant isolate, $\mathrm{RC} 1 \# 10$, was also unable to grow at this concentration (data not shown).

Isolates of $P$. palmivora and the isolate of $P$. cinnamomi displayed an extremely sensitive phenotype. After 4 months of incubation, it was not possible to obtain mycelia to perform the second transfers to assess acquisition of resistance to mefenoxam. Mefenoxamacquired resistance assays were successfully performed for isolates of P. betacei, the isolate of P. pseudocryptogea, and the isolates of Phytopythium sp.

All isolates of $P$. betacei and Phytopythium sp. acquired resistance to mefenoxam after being exposed to 1 and $5 \mu \mathrm{g} \mathrm{ml}^{-1}$. However, they presented variable responses depending on whether they were growing at $5 \mu \mathrm{g} \mathrm{ml}^{-1}$ or at $100 \mu \mathrm{g} \mathrm{ml}^{-1}$ of mefenoxam. Isolates P1512-73 and SBC3\#10 of P. betacei and isolate 112 of Phytopythium sp. grew significantly more at 5 and $100 \mu \mathrm{g} \mathrm{ml}^{-1}$ after being exposed to sublethal concentrations of mefenoxam $(P<0.05$ when growing at $5 \mu \mathrm{g}$ $\mathrm{ml}^{-1}$ and $P<0.001$ when growing at $100 \mu \mathrm{g} \mathrm{ml}^{-1}$ for isolate $\mathrm{P} 1512-$ $73, P<0.001$ when growing at both 5 and $100 \mu \mathrm{g} \mathrm{ml}^{-1}$ for isolate SBC3\#10, and $P<0.001$ when growing at $5 \mu \mathrm{g} \mathrm{ml}^{-1}$ and $P<0.01$ when growing at $100 \mu \mathrm{g} \mathrm{ml}^{-1}$ for isolate 112) (Fig. 3B and D). When growing at both 5 and $100 \mu \mathrm{g} \mathrm{ml}^{-1}$, isolate 66 of Phytopythium sp. presented a notorious increase in mycelial growth. However, this was only significant when growing at $5 \mu \mathrm{g} \mathrm{m}^{-1}(P<0.01)$ and not at $100 \mu \mathrm{g} \mathrm{ml}^{-1}(P>0.05)$. Isolate N9035-62 of $P$. betacei also gained resistance to mefenoxam when growing at 5 and $100 \mu \mathrm{g}$ $\mathrm{ml}^{-1}$ after being exposed to 1 and $5 \mu \mathrm{g} \mathrm{ml}^{-1}$ of mefenoxam. However, this gain was not significant $(P>0.05$ when growing both at $5 \mu \mathrm{g} \mathrm{ml}^{-1}$ and at $100 \mu \mathrm{g} \mathrm{ml}^{-1}$ of mefenoxam).

Furthermore, the isolate of $P$. pseudocryptogea responded differently at 5 and $100 \mu \mathrm{g} \mathrm{ml}^{-1}$ depending on the previous concentration ( 1 or $5 \mu \mathrm{g} \mathrm{ml}^{-1}$ of mefenoxam) to which it was exposed. When exposed to $1 \mu \mathrm{g} \mathrm{ml}^{-1}$ of mefenoxam, significant growth in comparison with the isolate that had never been exposed was observed at both 5 and $100 \mu \mathrm{g} \mathrm{ml}^{-1}$ of the fungicide $(P<0.001)$. However, after being exposed to $5 \mu \mathrm{g} \mathrm{ml}^{-1}$ of mefenoxam, growth was not significantly different to that of the originally sensitive isolate at 5 and $100 \mu \mathrm{g}$ $\mathrm{ml}^{-1}$ of mefenoxam.

Fluopicolide-acquired resistance assays. In the fluopicolideacquired resistance assays, there was no evident gain in resistance in the originally sensitive isolates, IMK-1 and US150046, after they were exposed to sublethal concentrations of the fungicide. Isolate IMK-1 presented a significantly lower mycelial percent growth relative to the control at $0.5 \mu \mathrm{g} \mathrm{ml}^{-1}$ of fluopicolide $(P<0.05)$ after exposure to sublethal concentrations of fluopicolide than it did before being exposed to the fungicide. Moreover, none of these originally sensitive isolates was able to grow at the highest concentration tested (10 $\mu \mathrm{g} \mathrm{ml}^{-1}$ of fluopicolide) after being exposed to the sublethal concentrations of the fungicide. On the other hand, isolate RC1\#10 was able to grow at all concentrations tested. Mycelial radial growth for this isolate did not differ significantly after being exposed to sublethal concentrations of the fungicide $(P>0.1$ when growing at 0.5 and at $1 \mu \mathrm{g} \mathrm{ml}^{-1}$ of fluopicolide) (Fig. 3E).

Table 1. Initial sensitivity to the three systemic fungicides assessed in this study. Sensitivity to mefenoxam was assessed for isolates of Phytophthora infestans (US1500046, IMK-1, and RC1\#10), isolates of Phytophthora betacei (P1512-73, SBC3\#10, and N9035-62), isolates of Phytophthora palmivora (9, 10, and 88), one isolate of Phytophthora cinnamomi, one isolate of Phytophthora pseudocryptogea, and two isolates of Phytopythium sp. (112 and 66). Sensitivity to fluopicolide and cymoxanil was assessed for isolates of $P$. infestans (US1500046, IMK-1, and RC1\#10). The effective concentration at which 50\% of mycelial growth was suppressed $\left(\mathrm{EC}_{50}\right)$, for each isolate on each fungicide is shown.

\begin{tabular}{|c|c|c|c|c|c|}
\hline & & & Mefenoxam & Fluopicolide & Cymoxanil \\
\hline Species & Lineage & Isolate & $\mathrm{EC}_{50}\left(\mu \mathrm{g} \mathrm{ml}^{-1}\right) \pm$ C.I. $95 \%$ & $\overline{\mathrm{EC}_{50}\left(\mu \mathrm{g} \mathrm{ml}^{-1}\right) \pm \text { C.I. } 95 \%}$ & $\mathrm{EC}_{50}\left(\mu \mathrm{g} \mathrm{ml}^{-1}\right) \pm$ C.I. $95 \%$ \\
\hline P. infestans & US-23 & US150046 & $1.89 \mathrm{e}^{-01}\left(0.53 \mathrm{e}^{-01}, 3.59 \mathrm{e}^{-01}\right)$ & $0.65(0.421,0.991)$ & $0.63(0.490,0.79)$ \\
\hline P. infestans & US-22 & IMK-1 & $2.21 \mathrm{e}^{-01}\left(1.14 \mathrm{e}^{-01}, 3.49 \mathrm{e}^{-01}\right)$ & $1.09(0.604,2.122)$ & $0.20(0.175,0.22)$ \\
\hline P. infestans & EC-1 & $\mathrm{RC} 1 \# 10$ & $>100.0$ & $0.18(x, 1.074)^{\mathrm{a}}$ & $2.02(1.549,2.663)$ \\
\hline P. betacei & $\mathrm{NA}^{\mathrm{b}}$ & $\mathrm{P} 1512-73$ & $4.55 \mathrm{e}^{-06}(x, x)$ & NA & NA \\
\hline P. betacei & NA & SBC3\#10 & $0.06 \mathrm{e}^{-01}\left(x, 0.26 \mathrm{e}^{-01}\right)$ & NA & NA \\
\hline P. betacei & NA & N9035-62 & $0.14\left(3.57 \mathrm{e}^{-03}, 3.04 \mathrm{e}^{-01}\right)$ & NA & NA \\
\hline P. palmivora & NA & 9 & $9.98 \mathrm{e}^{-04}\left(x, 2.95 \mathrm{e}^{-02}\right)$ & NA & NA \\
\hline P. palmivora & NA & 10 & $7.83 \mathrm{e}^{-04}\left(x, 2.87 \mathrm{e}^{-02}\right)$ & NA & NA \\
\hline P. palmivora & NA & 88 & $3.74 \mathrm{e}^{-03}\left(x, 2.90 \mathrm{e}^{-02}\right)$ & NA & NA \\
\hline P. cinnamomi & NA & P. cinnamomi & $1.99 \mathrm{e}^{-03}\left(x, 2.87 \mathrm{e}^{-02}\right)$ & NA & NA \\
\hline P. pseudocryptogea & NA & P. pseudocryptogea & $4.63 \mathrm{e}^{-04}\left(x, 3.53 \mathrm{e}^{-02}\right)$ & NA & NA \\
\hline Phytopythium sp. & NA & 112 & $2.17 \mathrm{e}^{-03}\left(x, 2.97 \mathrm{e}^{-02}\right)$ & NA & NA \\
\hline Phytopythium sp. & NA & 66 & $2.06 \mathrm{e}^{-03}\left(x, 2.05 \mathrm{e}^{-02}\right)$ & NA & NA \\
\hline
\end{tabular}

a $x$ : In some cases, more data points were needed in order to calculate one of the $95 \%$ confidence interval limit values.

b NA: Data not available. 
Cymoxanil-acquired resistance assays. As in the case of the fluopicolide-acquired resistance assays, originally sensitive isolates of $P$. infestans (US150046, IMK-1, and RC1\#10) did not in general acquire resistance to cymoxanil after exposure to sublethal concentrations of this fungicide. Isolate US150046 maintained its original growth pattern regardless of its previous exposure, while mycelial percent growth relative to the control for isolate IMK-1 decreased significantly when growing at $10 \mu \mathrm{g} \mathrm{ml}^{-1}$ of cymoxanil after being exposed to 1 and $10 \mu \mathrm{g} \mathrm{ml}^{-1}$ of cymoxanil $(P<0.05)$. Surprisingly, mycelial percent growth relative to the control for isolate RC1\#10, which exhibits resistance to mefenoxam and fluopicolide, increased significantly when growing at $10 \mu \mathrm{g} \mathrm{ml}^{-1}$ after being exposed to sublethal concentrations of 1 and $10 \mu \mathrm{g} \mathrm{ml}^{-1}$ of cymoxanil $(P<0.01)$. However, none of the isolates was able to
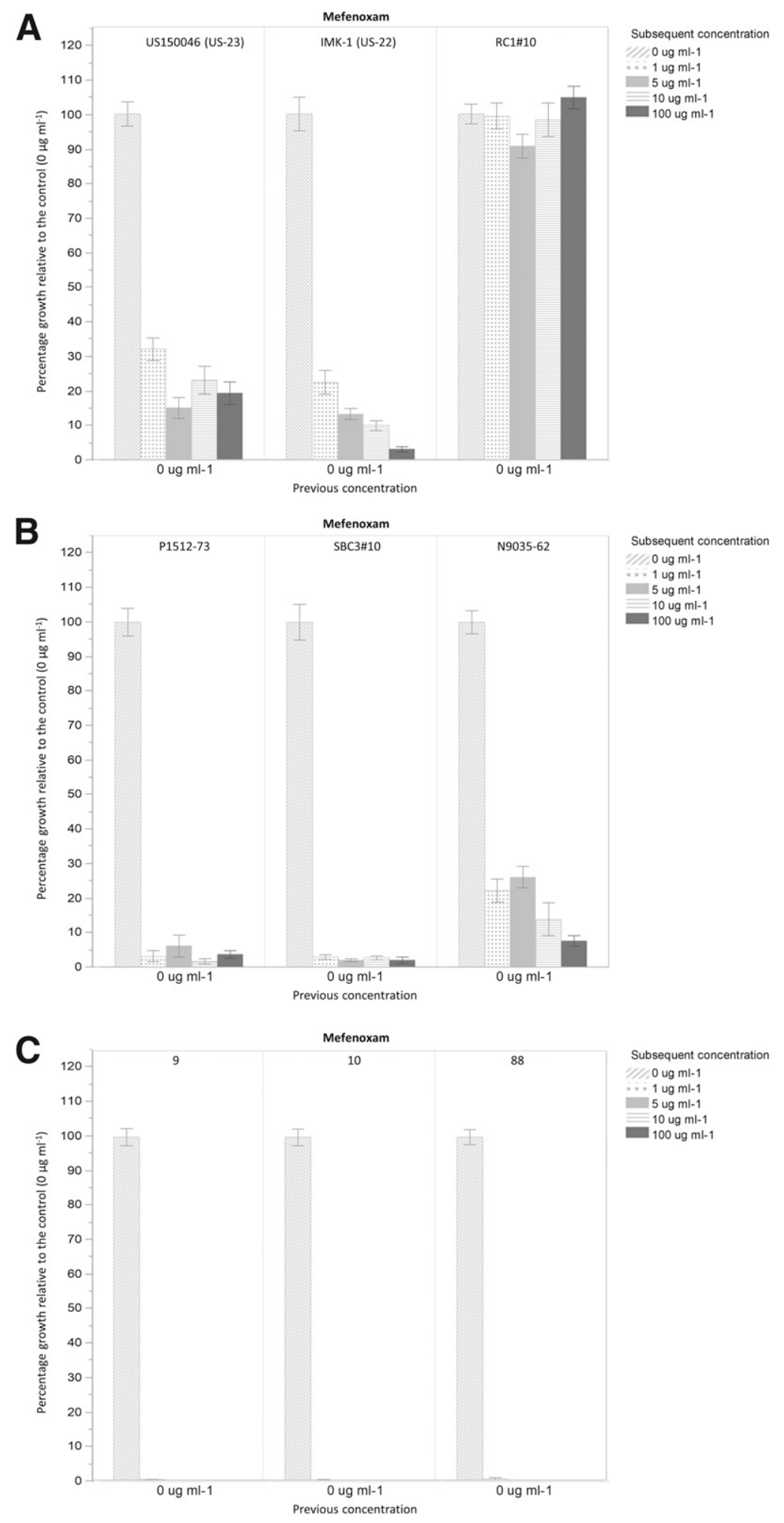

(Continued)

Fig. 2. Initial sensitivity to the three systemic fungicides assessed in this study. Sensitivity to mefenoxam was assessed for A, isolates of Phytophthora infestans (US1500046, IMK-1, and RC1\#10), B, isolates of Phytophthora betacei (P1512-73, SBC3\#10, and N9035-62), C, isolates of Phytophthora palmivora (9, 10, and 88), D, one isolate of Phytophthora cinnamomi and one isolate of Phytophthora pseudocryptogea, and $\mathbf{E}$, two isolates of Phytopythium sp. (112 and 66). Sensitivity to fluopicolide (F) and cymoxanil (G) was assessed for isolates of $P$. infestans (US1500046, IMK-1, and RC1\#10). Error bars represent one standard error from the mean. 
grow at the highest concentration tested $\left(100 \mu \mathrm{g} \mathrm{ml}^{-1}\right.$ of cymoxanil) (Fig. 3F).

Effect of the acquisition of resistance on growth rate. A clear effect of the acquisition of resistance on the growth rate of the isolates was evident for the mefenoxam-acquired resistance assay. All isolates that acquired resistance to mefenoxam regardless of the species (US150046, IMK-1, P1512-73, SBC3\#10, N9035-62, the isolate of $P$. pseudocryptogea) grew at a significantly slower rate after being exposed to sublethal concentrations of the fungicide when compared with their growth rate before being exposed to mefenoxam (Fig. 4A to D). This was also observed for the two isolates belonging to Phytopythium sp. (112 and 66), which also acquired resistance to the fungicide. In contrast, the initially resistant isolate $(\mathrm{RC} 1 \# 10)$ presented a significantly faster growth after being exposed through sublethal concentrations of mefenoxam $(P<0.01)$ (Fig. 4A).

The number of days it took for $P$. infestans isolates to reach 80 to $90 \%$ of the control plate before and after exposure to fluopicolide only differed significantly for isolate US150046 $(P<0.05)$. However, these differences lack a clear growth pattern, growing faster after being exposed to $0.1 \mu \mathrm{g} \mathrm{ml}^{-1}$ and slower after being exposed to $0.5 \mu \mathrm{g} \mathrm{ml}^{-1}$ (Fig. 4E). Similarly, for the cymoxanil-acquired resistance assays, only isolate RC1\#10 presented a significantly slower growth rate depending on its previous fungicide exposure $(P<0.001)$ (Fig. 4F). All other isolates lacked significant differences in the number of days they took to reach 80 to $90 \%$ in these fungicides.

\section{Discussion}

In this study, we did not observe the phenomenon of acquired resistance in $P$. infestans after exposure to fluopicolide or to cymoxanil. However, acquired resistance to mefenoxam also occurs in all other Phytophthora species that we were able to access, as well as in two isolates of a closely related plant-pathogenic oomycete, Phytopythium sp. The isolates' growth rate on the control plates (media with no fungicide) decreased after acquisition of resistance to mefenoxam but remained unaltered after sublethal exposure to fluopicolide and cymoxanil.

$P$. infestans isolates US150046 and IMK-1 that were initially sensitive to mefenoxam acquired resistance after a single exposure through sublethal concentrations of this fungicide. Such a fast acquisition of mefenoxam resistance has only been reported previously by Childers et al. (2015). The acquisition of resistance reported by Staub et al. (1979) and Bruin and Edgington (1981) was assessed after four and 12 consecutive transfers in medium amended with sublethal concentrations of furalaxyl and metalaxyl, respectively.

Isolates of $P$. betacei, $P$. pseudocryptogea, and Phytopythium sp. that were originally sensitive to mefenoxam also acquired resistance to this fungicide after a single exposure through sublethal

Fig. 2. (Continued from previous page)
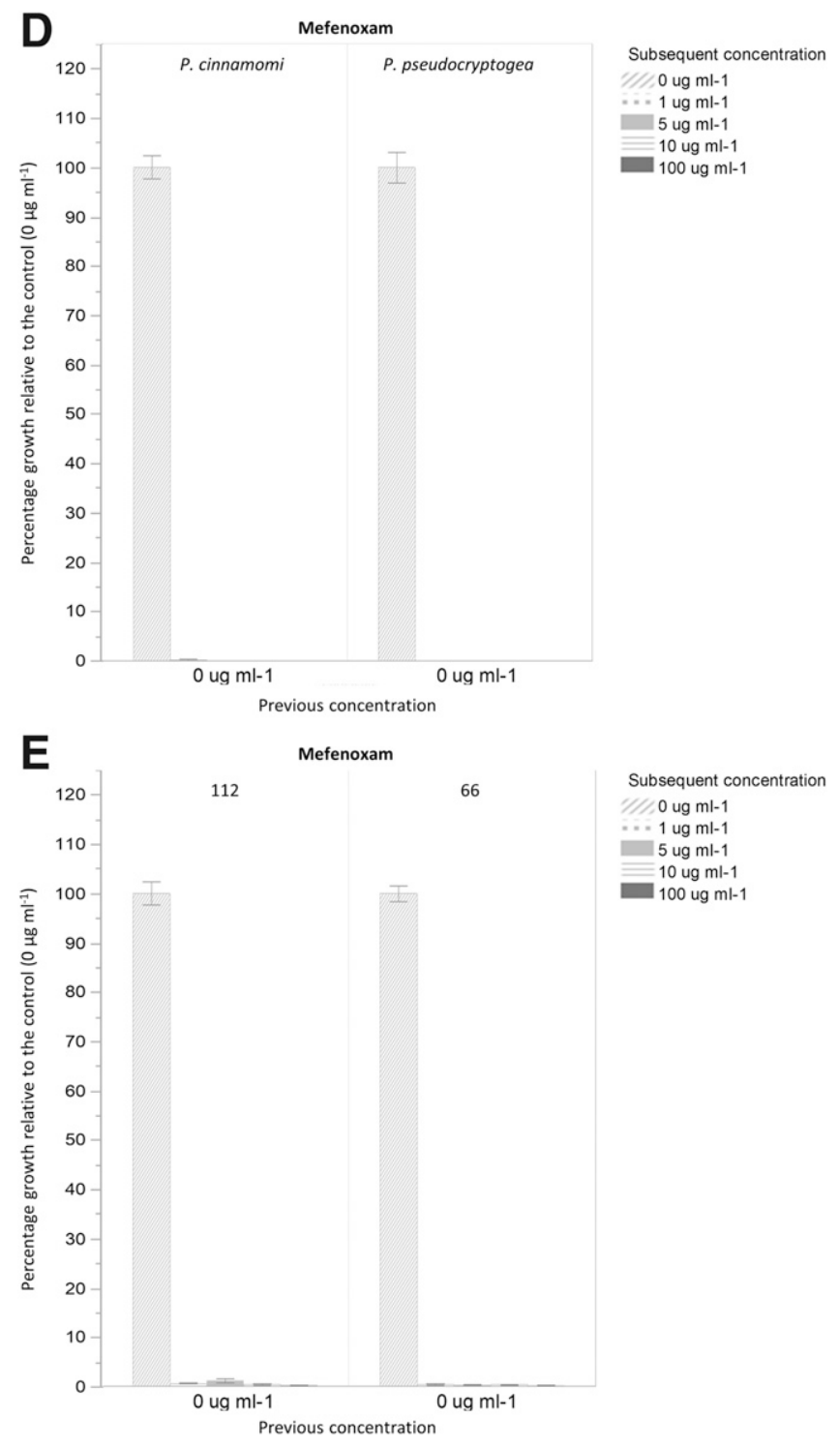

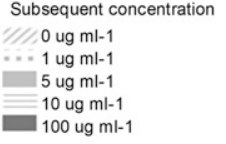


concentrations of mefenoxam. This shows that the phenomenon is not unique to $P$. infestans and may occur in different species within the genus. In this same sense, Bruin and Edgington (1981) reported that the phenomenon of acquisition of resistance also occurred in P. capsici.

Interestingly, the acquisition of resistance was more evident in these species than it was in $P$. infestans because they were originally more sensitive to mefenoxam than $P$. infestans isolates. So far, all $P$. betacei isolates collected from both the central and the southern regions of Colombia are sensitive to mefenoxam (M. Parra, N. Guayazán, G. Danies, M. F. Mideros, N. Vargas, L. E. Lagos, and $\mathrm{S}$. Restrepo, unpublished results). The absence of $P$. betacei isolates that are resistant to mefenoxam and their acquisition of resistance suggests that a constant monitoring of the sensitivity to this fungicide is important. However, as of today, mefenoxam may be recommended to growers to control the disease caused by $P$. betacei on tree tomato (Solanum betaceum) crops.

Very limited information on the pathogenicity, response to fungicides, and other characteristics of $P$. pseudocryptogea, is currently available. However, it has been found to be among the most pathogenic species on Australian forests (Khdiar 2018). Therefore, knowing about their response to fungicides is important. Phytopythium sp. is commonly found in water tanks and areas with irrigation of water (Choudhary et al. 2016). Isolates of Phytopythium sp. highly sensitive (Choudhary et al. 2016; Radmer et al. 2017), intermediate (Choudhary et al. 2016), and insensitive to mefenoxam (Demott 2015) have been reported. Thus, knowledge on the sensitivity of this species to this fungicide is relevant.

A cost in growth rate was evident for all Phytophthora species that were assessed, after acquisition of resistance. This could indicate the existence of a mechanism that allows them to survive when being exposed to a selective pressure such as the fungicide, but that implies a trade-off in the isolate's growth. Childers et al. (2015) suggested that there was a fitness cost associated to the acquisition of resistance in $P$. infestans. This was further supported in this study by the significant increase in the number of days it took for all initially sensitive isolates to reach 80 to $90 \%$ of the control plate after being exposed to sublethal concentrations of mefenoxam. Bruin and Edgington (1981) had also previously reported that adapted strains on unamended V8 agar grew 20 to $30 \%$ slower than their parent strains (never exposed to the fungicide). Interestingly, the originally resistant isolate (RC1\#10) grew significantly faster after exposure to sublethal concentrations of mefenoxam.

Unfortunately, an originally resistant isolate to cymoxanil was not available to evaluate how it would respond to sublethal concentrations of the fungicide. To the best of our knowledge, no isolates resistant to cymoxanil have been reported. Saville et al. (2015) found no resistant isolates of $P$. infestans when exposing them to a variety of concentrations that ranged up to $100 \mu \mathrm{g} \mathrm{ml}^{-1}$. This is a much higher concentration when compared with those used in other in vitro experiments, where the highest concentrations assessed for cymoxanil are $50 \mu \mathrm{g} \mathrm{ml}^{-1}$ (Keinath 2007) or even $4 \mu \mathrm{g} \mathrm{ml}^{-1}$ (Perez et al. 2009). The isolates tested were not able to grow at higher concentrations, generating $\mathrm{EC}_{50}$ values between 0.03 and $1.11 \mu \mathrm{g} \mathrm{ml}^{-1}$ (Perez et al. 2009).

Most of the isolates did not differ in their growth rate before and after exposure to sublethal concentrations of fluopicolide or cymoxanil. This further supports the idea that there is no change in the isolates when previously exposed to sublethal concentrations of these fungicides. However, isolate RC1\#10 was the only one that seemed to increase its growth relative to the control in a significant way after being exposed to sublethal concentrations of cymoxanil. This apparent acquisition of resistance only occurred when being exposed to the originally sublethal concentration of $10 \mu \mathrm{g} \mathrm{ml}^{-1}$ and not to the originally lethal concentration of $100 \mu \mathrm{g} \mathrm{ml}^{-1}$. However, because of the notorious sensitivity that $P$. infestans isolates present to cymoxanil, we believe that the concentration of $100 \mu \mathrm{g} \mathrm{ml}^{-1}$ might be too high for even resistant isolates to grow. Therefore, further experiments are needed to

Fig. 2. (Continued from previous page)
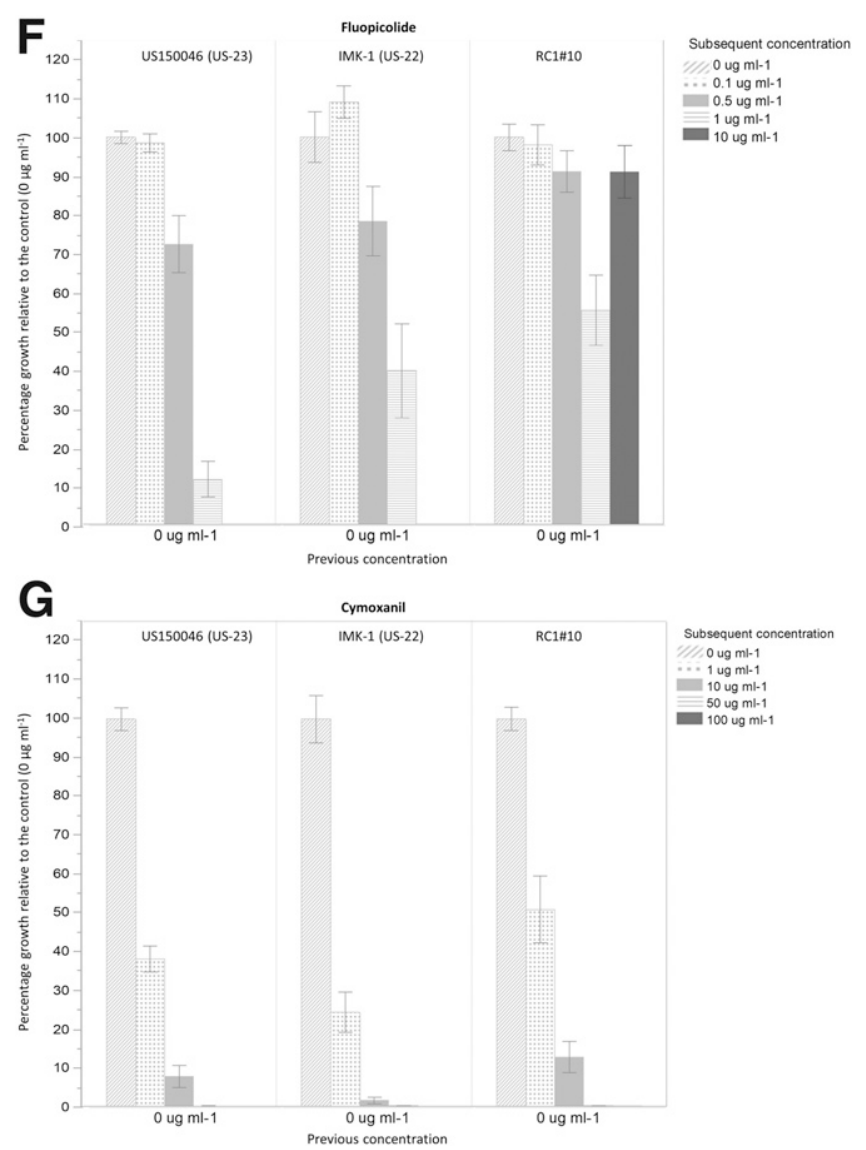
test if isolate RC1\#10 will be able to grow at a concentration lower than $100 \mu \mathrm{g} \mathrm{ml}^{-1}$ but higher than $10 \mu \mathrm{g} \mathrm{ml}^{-1}$ after being exposed to sublethal concentrations of this fungicide. Interestingly, this same isolate grew significantly more slowly on the control plate after exposure to cymoxanil, exhibiting the same pattern observed for the isolates that acquire resistance to mefenoxam.

So far, it has been shown that mefenoxam affects the synthesis of rRNA by specifically interfering with the incorporation of uridine by the RNA Pol I (Davidse et al. 1988; Fisher and Hayes

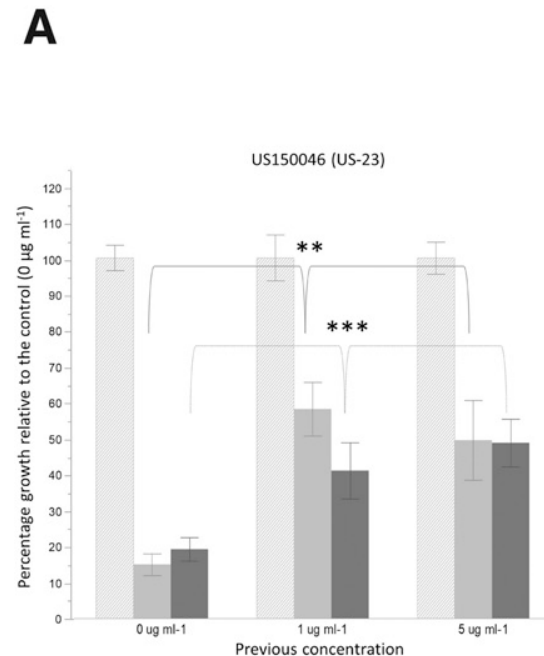

B
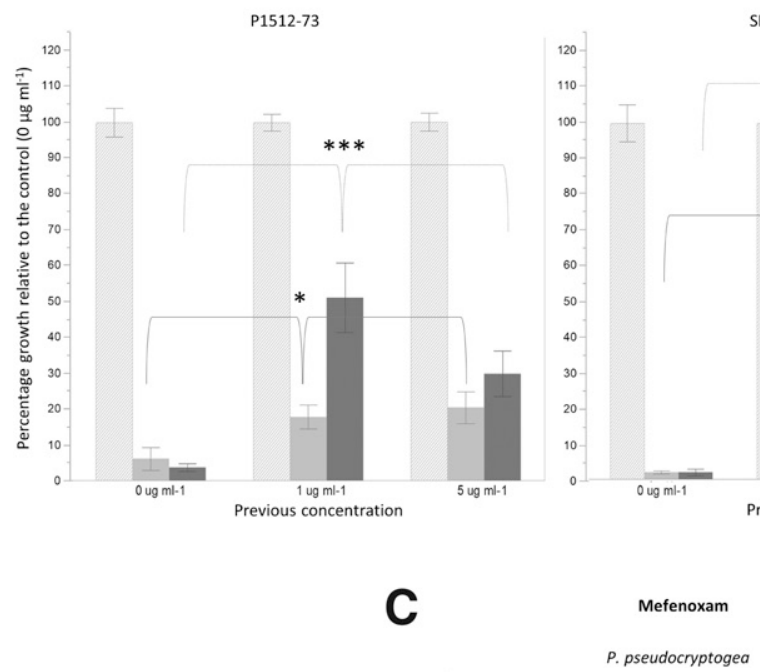

IMK-1 (US-22)
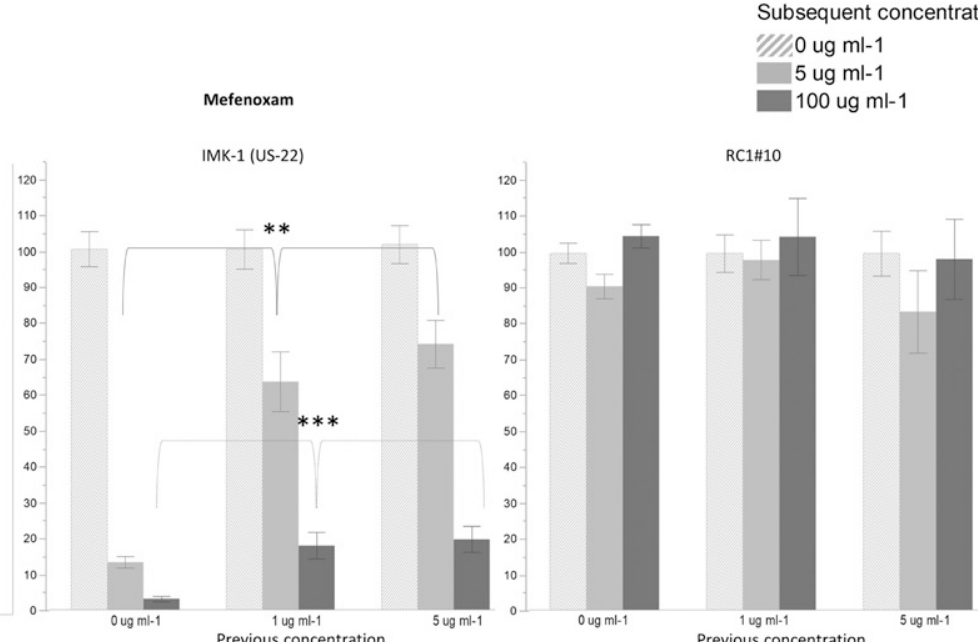

100 ug $\mathrm{ml}-1$

Subsequent concentration I/// 0 ug $\mathrm{ml}-1$

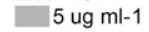

100 ug ml-1

N9035-62

Subsequent concentration W// $/ 0$ ug ml-1

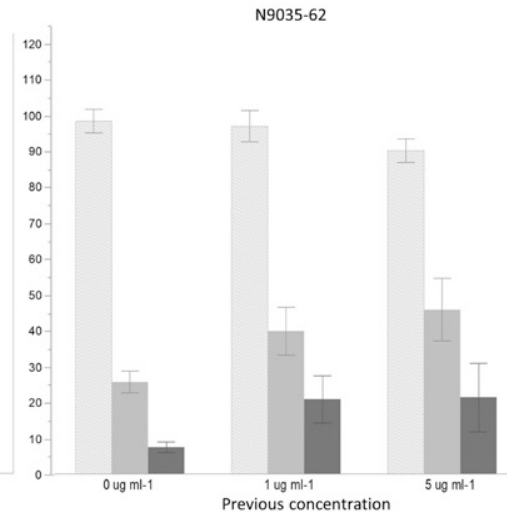

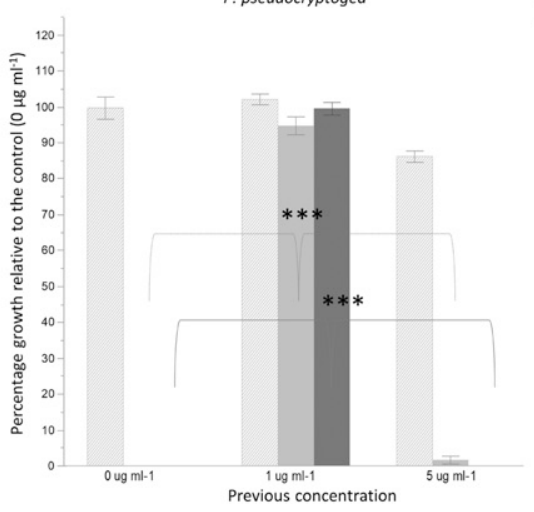

100 ug $\mathrm{ml}-1$

(Continued on next page)

Fig. 3. Assessment of acquisition of resistance assays to mefenoxam, fluopicolide, and cymoxanil. Acquired resistance to mefenoxam was assessed for $\mathbf{A}$, three isolates of Phytophthora infestans (US1500046, IMK-1, and RC1\#10), B, three isolates of Phytophthora betacei (P1512-73, SBC3\#10, and N9035-62), C, one isolate of Phytophthora pseudocryptogea, and $\mathbf{D}$, two isolates of Phytopythium sp. (112 and 66). For fluopicolide (E) and cymoxanil (F) acquired resistance was assessed only for isolates of $P$. infestans (US1500046, IMK-1, and RC1\#10). Error bars represent one standard error from the mean. Significant differences in mycelial growth at each subsequent

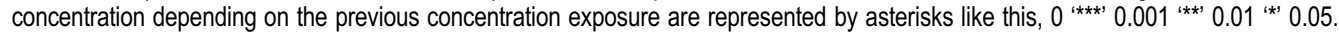


1982; Matson et al. 2015). It has also been suggested that the stable natural resistance to mefenoxam might be caused by a mutation on one of the subunits of this enzyme (Davidse and van den BergVelthuis 1989; Randall et al. 2014). However, there is no current agreement on the mechanism by which the phenomenon of acquired resistance nor the stable resistance to mefenoxam works. Additionally, candidate genes that might be involved in the phenomenon of acquired resistance were identified by Childers et al. (2015).

D

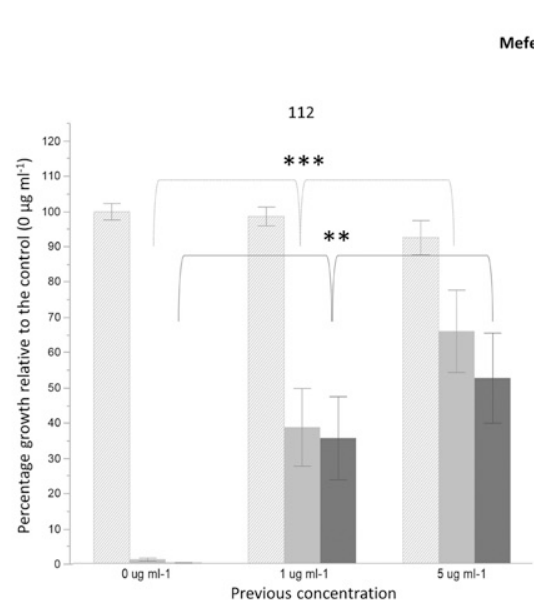

\section{Fig. 3. (Continued from previous page)}

Childers et al. (2015) reported that isolates that had acquired resistance to mefenoxam slightly recovered sensitivity to the fungicide after being repeatedly cultured on pea agar without fungicide. Furthermore, Bruin and Edgington (1981) reported that the stability of the acquired resistance varied among $P$. capsici isolates. One isolate was able to recover its original sensitivity completely after several transfers to unmodified V8 agar, one reverted to an intermediate level of sensitivity, and the other retained the resistance that it had acquired. Because of the apparent reversibility of the phenomenon, the fact that it has been

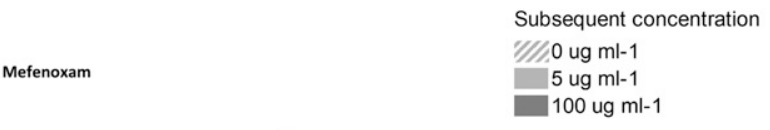

$\mathbf{E}$
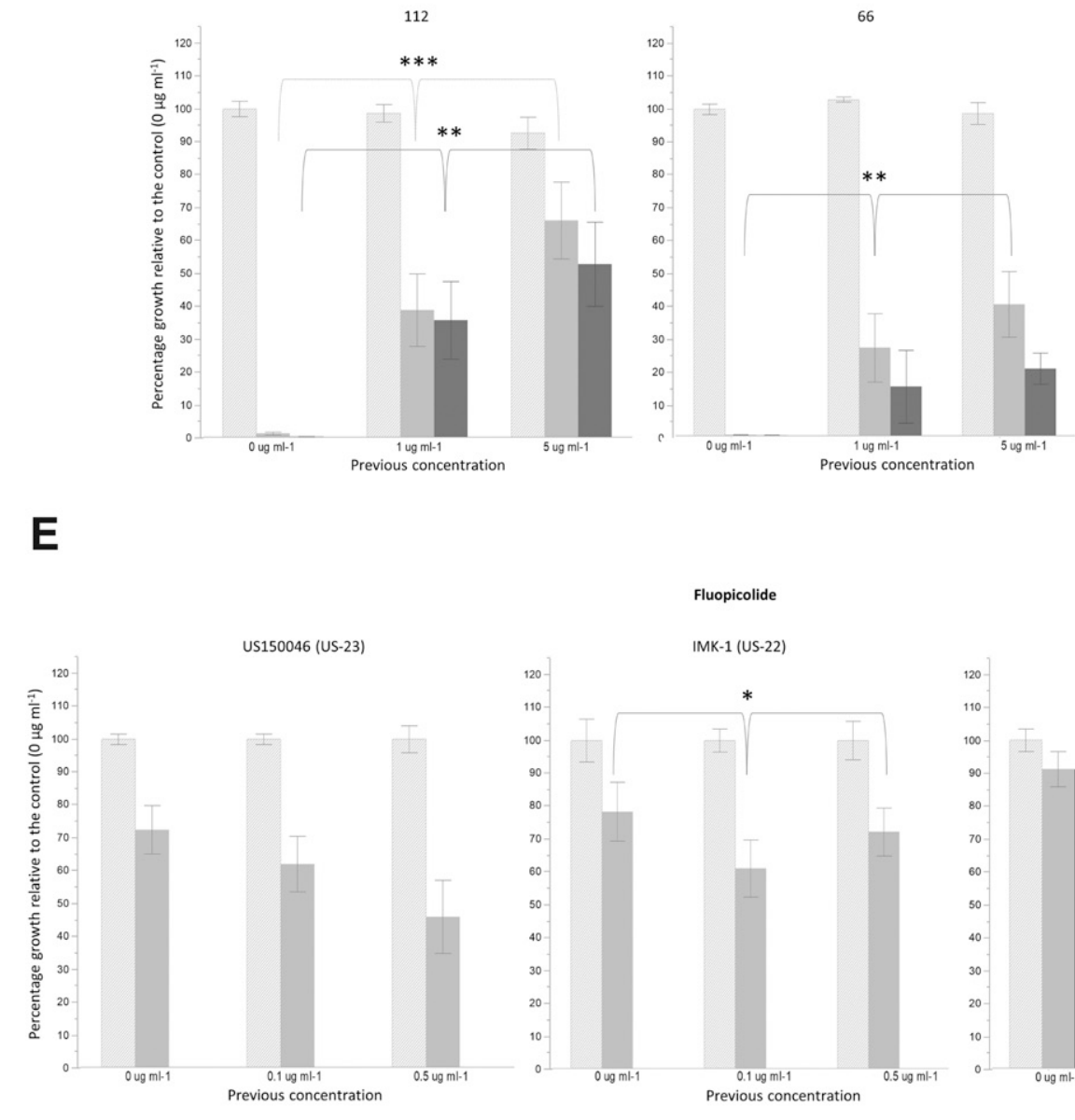

Subsequent concentration 1/// 0 ug $\mathrm{ml}-1$

0.5 ug $\mathrm{ml}-1$ 10 ug ml-1

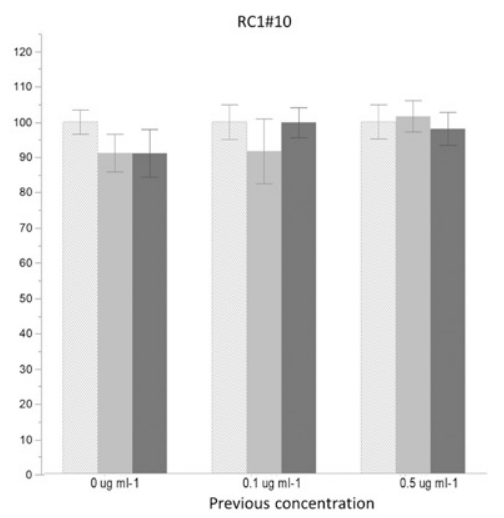

$\mathbf{F}$

Subsequent concentration W// 0 ug $\mathrm{ml}-1$

10 ug ml-1
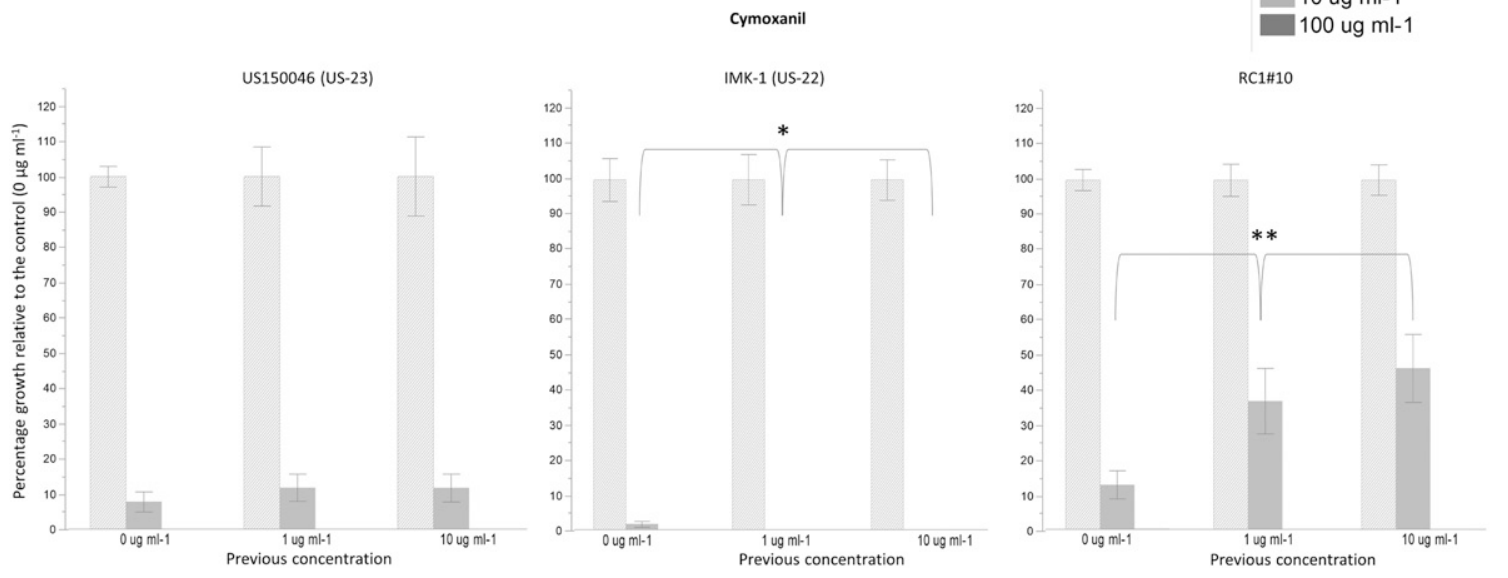
reported in distinct genotypes of $P$. infestans and in different species of Phytophthora (Bruin and Edgington 1981) and that it occurs after a single transfer, it is highly unlikely that a mutation is the mechanism underlying it (Childers et al. 2015). Therefore, an epigenetic mechanism has been hypothesized for its regulation.
Research on the possible molecular mechanisms associated to this phenomenon are currently being carried out in our lab. So far, we have determined that a phenotype similar to that of a pleiotropic drug resistance phenomenon might be mediating the acquisition of resistance to mefenoxam in P. infestans (J. González-Tobón,
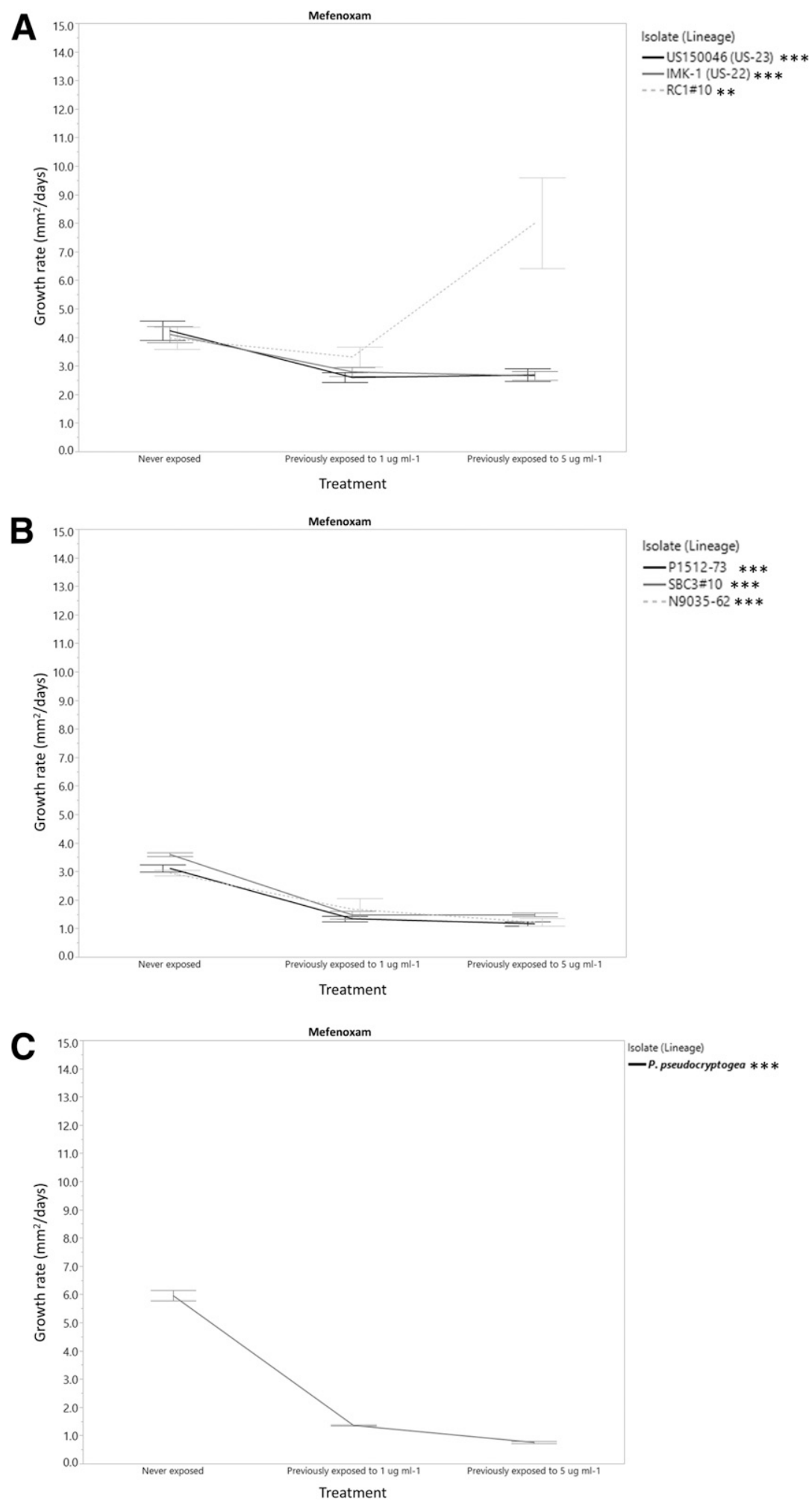

(Continued on next page)

Fig. 4. Assessment of the growth rate $\left(\mathrm{mm}^{2} \mathrm{day}^{-1}\right)$ on the control plates $\left(0 \mu \mathrm{g} \mathrm{ml}^{-1}\right)$ of the isolates after exposure through fungicide-containing medium. Days it took for isolates to reach 80 to $90 \%$ of the petri plate on the control $\left(0 \mu \mathrm{g} \mathrm{ml}^{-1}\right)$ after being exposed to mefenoxam-containing medium for $\mathbf{A}$, three isolates of Phytophthora infestans (US1500046, IMK-1, and RC1\#10), B, three isolates of Phytophthora betacei (P1512-73, SBC3\#10, and N9035-62), C, one isolate of Phytophthora pseudocryptogea, and D, two isolates of Phytopythium sp. (112 and 66). For fluopicolide (E) and cymoxanil (F) the growth rate was assessed only for isolates of $P$. infestans (US1500046, IMK-1, and RC1\#10). Significant

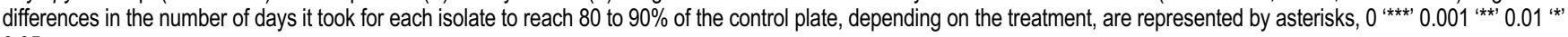
0.05 . 
R. Childers, W. Fry, K. L. Myers, A. Rodríguez, K. L. Perry, J. R. Thompson, S. Restrepo, and G. Danies, unpublished). This type of phenomenon is strongly dependent on the amount of fungicide inside the cell as well as on the cell's capacity to trigger downstream transporting and enzymatic mechanisms to expel the chemical. Interestingly, the isolate we tested for $P$. pseudocryptogea was only able to acquire resistance when being exposed to $1 \mu \mathrm{g} \mathrm{ml}^{-1}$, but not to $5 \mu \mathrm{g} \mathrm{ml}^{-1}$ of mefenoxam. This may suggest that the cell's capacity to expel the fungicide will depend on the amount of fungicide inside the cell.

The assessment of this phenomenon in vivo is necessary. Bruin and Edgington (1981) reported that $P$. infestans did not seem to adapt to the fungicide when tested on potato tubers, which was supported previously by Staub et al. (1979) on tomato and potato plants. Furthermore, an understanding of the effect of acquisition of resistance on the isolates' aggressiveness and virulence on the host is important.

Fig. 4. (Continued from previous page)

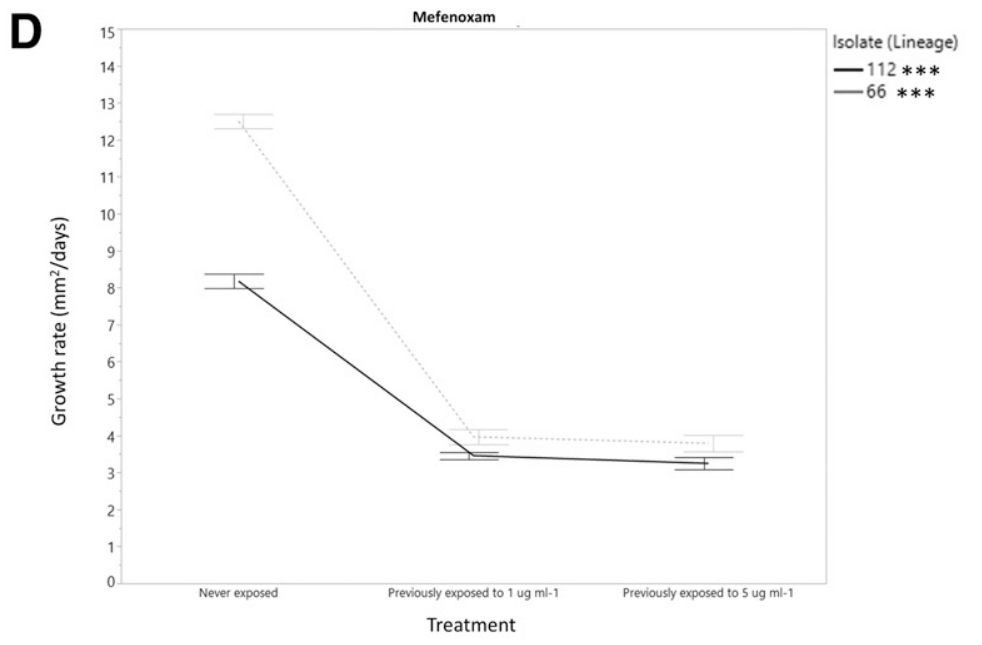

$\mathbf{E}$

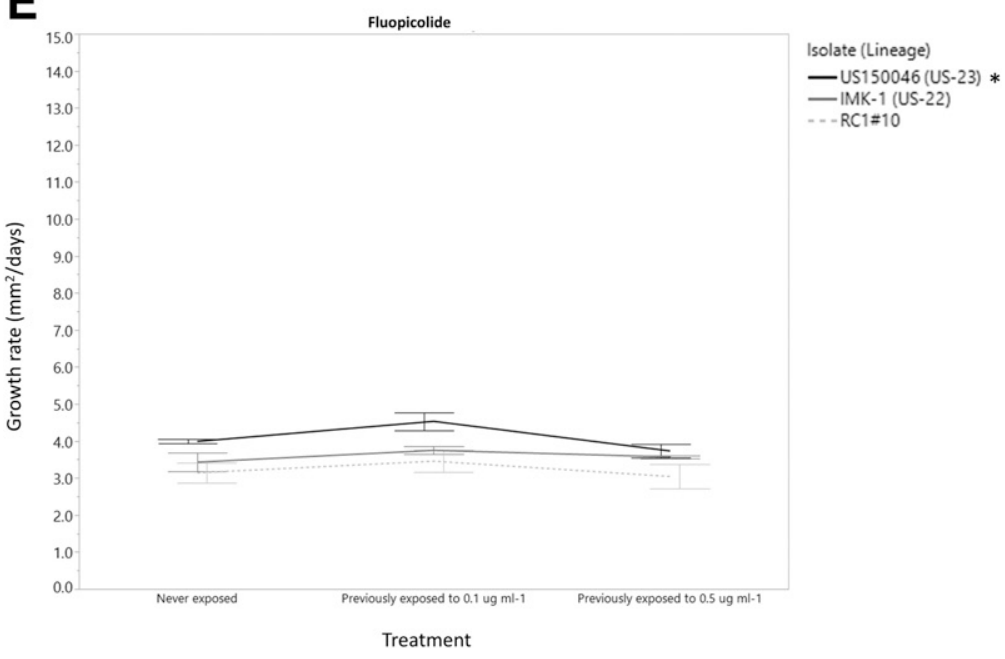

$\mathbf{F}$

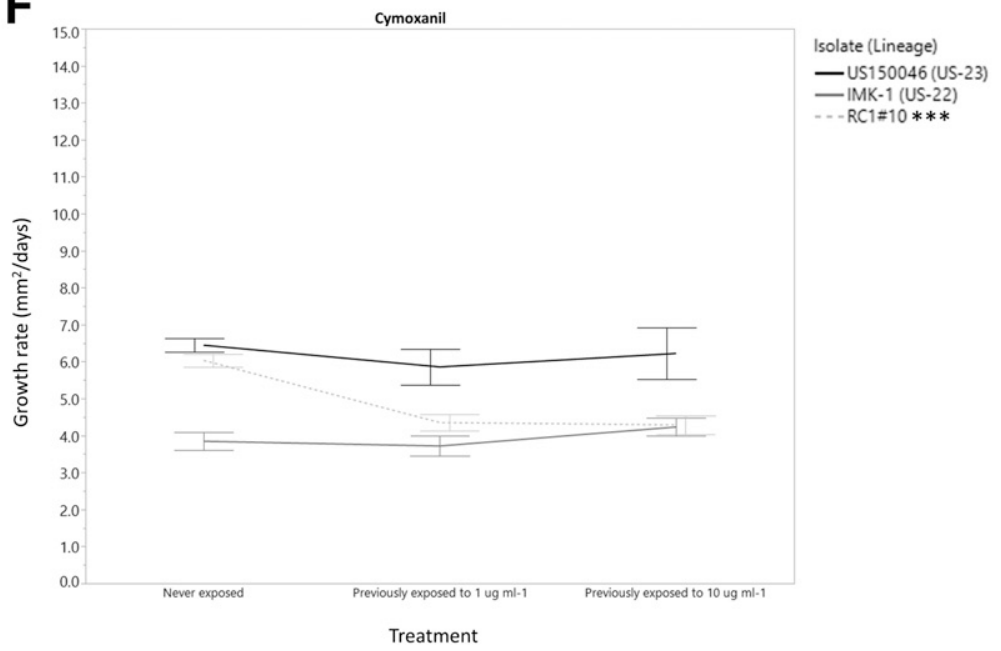


Lastly, the effect of this phenomenon on sporangia production should also be assessed.

\section{Acknowledgments}

We thank Mauricio Soto-Suárez from Agrosavia for his valuable support during the execution of these experiments. We thank Bayer for providing some of the fungicides that were tested.

\section{Literature Cited}

Bruin, G. C. A., and Edgington, L. V. 1981. Adaptive resistance in Peronosporales to metalaxyl. Can. J. Plant Pathol. 3:201-206.

Childers, R., Danies, G., Myers, K., Fei, Z., Small, I. M., and Fry, W. E. 2015. Acquired resistance to mefenoxam in sensitive isolates of Phytophthora infestans. Phytopathology 105:342-349.

Choudhary, C. E., Burgos-Garay, M. L., Moorman, G. W., and Hong, C. 2016. Pythium and Phytopythium species in two Pennsylvania greenhouse irrigation water tanks. Plant Dis. 100:926-932.

Davidse, L. C., Gerritsma, O. C., Ideler, J., Pie, K., and Velthuis, G. C. 1988. Antifungal modes of action of metalaxyl, cyprofuram, benalaxyl and oxadixyl in phenylamide-sensitive and phenylamide-resistant strains of Phytophthora megasperma f. sp. medicaginis and Phytophthora infestans. Crop Prot. 7: 347-355.

Davidse, L. C., and van den Berg-Velthuis, G. C. 1989. Biochemical and molecular aspects of the phenylamide fungicide-receptor interaction in plant pathogenic Phytophthora spp. Pages 261-266 in: Signal Molecules in Plants and PlantMicrobe Interactions. B. J. J. Lugtenberg, ed. Springer, Berlin.

Demott, M. E. 2015. Identification and mefenoxam sensitivity of oomycete root pathogens recovered from ornamental plants in Georgia. (Ph.D. diss., uga).

Fisher, D. J., and Hayes, A. L. 1982. Mode of action of the systemic fungicides furalaxyl, metalaxyl and ofurace. Pest Manag. Sci. 13:330-339.

FRAC. 2017. FRAC (Fungicide Resistance Action Committee) Mode of Action Poster. CropLife International.

Groves, C. T., and Ristaino, J. B. 2000. Commercial fungicide formulations induce in vitro oospore formation and phenotypic change in mating type in Phytophthora infestans. Phytopathology 90:1201-1208.

Hu, C.-H., Perez, F. G., Donahoo, R., McLeod, A., Myers, K., Ivors, K., Secor, G., Roberts, P. D., Deahl, K. L., Fry, W. E., and Ristaino, J. B. 2012. Recent genotypes of Phytophthora infestans in the eastern United States reveal clonal populations and reappearance of mefenoxam sensitivity. Plant Dis. 96:1323-1330.

Jaime-García, R., Trinidad-Correa, R., Felix-Gastelum, R., Orum, T. V., Wasmann, C. C., and Nelson, M. R. 2000. Temporal and spatial patterns of genetic structure of Phytophthora infestans from tomato and potato in the Del Fuerte Valley. Phytopathology 90:1188-1195.

Kamoun, S., Furzer, O., Jones, J. D., Judelson, H. S., Ali, G. S., Dalio, R. J., et al. 2015. The Top 10 oomycete pathogens in molecular plant pathology. Mol. Plant Pathol. 16:413-434.

Keinath, A. P. 2007. Sensitivity of populations of Phytophthora capsici from South Carolina to mefenoxam, dimethomorph, zoxamide, and cymoxanil. Plant Dis. 91:743-748.

Keinath, A. P., and Kousik, C. S. 2011. Sensitivity of isolates of Phytophthora capsici from the eastern United States to fluopicolide. Plant Dis. 95:1414-1419.

Khdiar, M. 2018. Detection, assessment, and management of Phytophthora species in an urban forest (Ph.D. diss., Murdoch University).

Li, J. L., Liu, X. Y., Xie, J. T., Di, Y. L., and Zhu, F. X. 2015. A comparison of different estimation methods for fungicide EC50 and EC95 values. J. Phytopathol. 163:239-244.

Matson, M. E. H., Small, I. M., Fry, W. E., and Judelson, H. S. 2015. Metalaxyl resistance in Phytophthora infestans: Assessing role of RPA190 gene and diversity within clonal lineages. Phytopathology 105:1594-1600.

Perez, W., Lara, J., and Forbes, G. A. 2009. Resistance to metalaxyl-M and cymoxanil in a dominant clonal lineage of Phytophthora infestans in Huánuco, Peru, an area of continuous potato production. Eur. J. Plant Pathol. 125:87-95.

R Core Team. 2012. R: A Language and Environment for Statistical Computing. Vienna. http://www.R-project.org.

Radmer, L., Anderson, G., Malvick, D. M., Kurle, J. E., Rendahl, A., and Mallik, A. 2017. Pythium, Phytophthora, and Phytopythium spp. associated with soybean in Minnesota, their relative aggressiveness on soybean and corn, and their sensitivity to seed treatment fungicides. Plant Dis. 101:62-72.

Randall, E., Young, V., Sierotzki, H., Scalliet, G., Birch, P., Cooke, D., Csukai, M., and Whisson, S. 2014. Sequence diversity in the large subunit of RNA polymerase I contributes to Mefenoxam insensitivity in Phytophthora infestans. Mol. Plant Pathol. 15:664-676.

Rekanović, E., Potočnik, I., Milijašević-Marčić, S., Stepanović, M., Todorović, B., and Mihajlović, M. 2011. Sensitivity of Phytophthora infestans (Mont.) de Bary isolates to fluazinam, fosetyl-Al and propamocarb-hydrochloride. Pestic. Fitomed. 26:111-116.

Saville, A., Graham, K., Grünwald, N. J., Myers, K., Fry, W. E., and Ristaino, J. B. 2015. Fungicide sensitivity of U.S. genotypes of Phytophthora infestans to six oomycete-targeted compounds. Plant Dis. 99:659-666.

Staub, T., Dahmen, H., Urech, P., and Schwinn, F. 1979. Failure to select for in vivo resistance in Phytophthora infestans against acylalanine fungicides. Plant Dis. Rep. 63:385-389. 